\title{
Critical Discourse Analysis of Lambe Turah Instagram Account as Post Truth Era Inauguration:
}

\author{
A Critical Discourse Analysis of Lambe Turah Instagram Account on Second Nyonyah \\ Edition
}

\author{
Rahmat Edi Irawan \\ Binus University \\ Jakarta, Indonesia \\ reirawan@yahoo.co.id
}

\author{
Merry Fridha \\ Universitas Islam Balitar \\ Blitar, Indonesia
}

\begin{abstract}
This research is trying to give a picture of the massive technology information and how it gets easier to access any information as it is served just by the end of our finger. One click is enough to give us access to the information we need. The speed of this information spread has made it a blade with two ends if the people do not have media literation that it can bring us to a post truth era, an era where we were made confused by too much information with its validation still in question as some lies or incorrect news are put as if it is a right one. In this era of flooding information, Lambe Turah shows up as a gossip account around celebrity's information with more than 4,4 million followers on Instagram. With its tagline, Gossip Is a Delayed Fact, this account became one of the trusted celeb gossip accounts in Instagram. Even one of private television media in Indonesia confirms some gossips they got to that account's administrator. It is tragic that television, which is truly the mass media with its gatekeepers to filter the incoming information, choose to trust a gossip account with no legal entity and authority in delivering a news. The result of this critical discourse analysis on micro level shows a certain trend of social discourse called pelakor shortened term for a man stealer. On the mezzo level, there can be seen a bias gesture of the account's administrator to the victim of the pelakor and an encouragement if cyber bullying by the netizen as a mean of punishment because pelakor is seen as parties who can destroy a household relationship. Meanwhile on the consumption section, that news receives a warm respond from the netizen. On macro level, situational, institutional and social factor have big influences on the information uploaded by Lambe Turah account. This account takes advantage on the freedom of information and legitimates the account's administrator needs which are orientated on neo liberal ideology, an ideology of reasonable information freedom which will inaugurate the Post Truth Era as netizen will be reluctant to verify the source of the information and unable to differentiate fact and fiction.
\end{abstract}

\section{Keywords - critical discourse analysis; instagram; post truth}

\section{INTRODUCTION}

Lambe Turah Instagram account is very phenomenal as can be seen on the number of followers which reaches up to 4,4 million people. Of course with the million followers, it's not wrong to crown this account as the biggest gossip account in Indonesia. An interpretation of gossip account is shown by the displayed profile photo which is a symbol of bright red lips and the use of the account name Lambe Turah which can be translated to cheap mouth or people who talk others overly and the image of Lambe Turah as a gossip account which always provides the hottest and newest information around famous celebrities fits perfectly. Moreover with its tagline that states that gossips are delayed facts, it only reinforce the accounts image as a frightening gossip account for the people they talk about.

\section{RESEARCH METHOD}

This research aims in exposing veiled discourse in Lambe Turah Instagram feeds. Using critical discourse analysis (CDA) method from Norman Fairclough [1], there are three level of analysis, started from micro level in the form of an analysis of a text feeds titled 'Second Nyonyah' which means second madam while in mezzo level it's an analysis of discourse act around the texts produced by Lambe Turah account and the netizens who consume it. Last, in macro level in the form of socio cultural analysis consists of situational, institutional and social analysis of what happen when a text feed titled 'Second Nyonyah' is produced.

\section{RESULTS AND DISCUSSION}

To verify the ideology behind Lambe Turah Instagram account, researchers see some detailed factors that would be analyzed. The post that would be an analysis unit of this research is titled second madam by the researchers. The name second madam is chosen as a title as it is used also by Lambe Turah account to refer to the third parties which becomes the main character of that post.

Information around pelakor or a man stealer is received by the account owner through direct messages from people who claims to be a relative of a woman who has been hurt by her husband as he got married again without any notice. That woman was shocked to found another woman who kept uploading her husband's picture intimately, until she uploaded pre-wedding and wedding pictorials with the victim's husband on her instagram account. After Lambe Turah accounts owner did some investigation, it turned out that the woman was 
Tyara_barbie, a pretty selebgram with follower up to 524.000 follower.

This information was uploaded at 13 and 14 January 2018. Researchers chose this post as nowadays pelakor term is often put as Valak (a ghost character) by the account owner. Based on micro analysis, pelakor discourse is a term frequently used by the community nowadays.

The term pelakor has become very famous after the actress Jennifer Dunn's case which pops up after she was accused of stealing a woman's husband. In daily life, gossips around public figures or famous people attain a lot of people interest and trigger public opinions. Quoting the result of research conducted by Vlad Petre Glavenanu titled Psychology in the Post Truth Era which stated that community will enjoy news around people in live and individual of the same gender more, or affair cases involving famous people. According to Vlad, gossip will also spread faster when it concerns positive information about their group and negative information about their rivals [2].

Gossiping can be very fun that is why every posts of Lambe Turah Instagram account is always flooded by comments from their followers who must like to gossip. In psychology, a fondness over gossiping can show how that person is more human and based on that reason, it is answered why gossip accounts such as Lambe Turah received so much interest from the netizen.

Based on the analysis on the phenomenon above, researchers see the existence of a social discourse that currently an issue concerning women who are accused of destroying a household, which is called as pelakor. This phenomenon is uploaded by Lambe Turah and received an outstandingly warm response from the netizen.

Lambe Turah: Journalism in New Style. With a good social media management stratify and aim specification in doing a clear social media, it is fitting to acknowledge that the existence of Lambe Turah is now stealing the public's attention. With the constant and frequent sensational news faster than other social or old media, this account seems as the stands only on two feet. One side being expected for their posts, but the on other they need to be ready to be bashed for it. A lot of Lambe Turah posts became viral in public and spread faster than the journalists of old media.

TABLE I. ANALYSIS BASED ON FAIRCLOUGH [3].

\begin{tabular}{|l|l|l|}
\hline \multicolumn{1}{|c|}{ Text } & \multicolumn{1}{|c|}{ Interpretation } & \multicolumn{1}{c|}{ Explanation } \\
\hline Second madam & Second wife & $\begin{array}{l}\text { A diss to the second } \\
\text { wife }\end{array}$ \\
\hline Valak & Ghost/ a man stealer & Not a good woman \\
\hline Cirengdough & $\begin{array}{l}\text { A mixed flour, done } \\
\text { by pressing and } \\
\text { squeezing it multiple } \\
\text { times }\end{array}$ & $\begin{array}{l}\text { An expression of } \\
\text { pique }\end{array}$ \\
\hline $\begin{array}{l}\text { If you agree you're } \\
\text { mental }\end{array}$ & $\begin{array}{l}\text { Looking for people } \\
\text { who disagree }\end{array}$ & $\begin{array}{l}\text { An expression of } \\
\text { disagreement }\end{array}$ \\
\hline Kiss emoticon & $\begin{array}{l}\text { An expression of } \\
\text { care, respect. }\end{array}$ & $\begin{array}{l}\text { With the add of kiss } \\
\text { emoticon, the writer } \\
\text { asked the followers } \\
\text { to agree on her } \\
\text { opinion through the } \\
\text { uploaded caption }\end{array}$ \\
\hline
\end{tabular}

From Table I, the mezzo level of analysis of text production according to Fairclough above shows a biased attitude of the writer of the post to the hurt legal wife, and that caption explained that it is fitting for a man stealer to be bashed [3]. The diss words used by Lambe Turah used Indonesian slank word and the diction chosen are funny and full of metaphor. Through the interview, the account's owners told us the reason of every caption put below their gossip posts:

"This whole time we always use a mannerly language which is not accusing or judging others at all. Even sometimes the photo and the caption written are not in line. But as they said, one picture million meanings. Except for valakor (Valak+pelakor), okay, Minceu really hate that creature."

Through a photo post and caption about second mada by Lambe Turah, researchers analyzed that according to the account's owners, a man stealer is indeed a dangerous party as she can destroy a household relationship. That is why it is fitting if a man stealer got a social punishment from the netizen in the for of cyber bullying. The account's owners also give some space for the netizen to do the cyber bullying through the sentence: "comment as you like" and "if you agree you are mental".

From the consumption side of the netizen, the news which are supposedly private or family matter now transformed into public consumption that's been waited by the mass. Clenching sensational news is pleasure for the consumers who preferred it. Viral beats up journalism regulation due to people's thirst of information. This is proven by the massive number of like and comment from the netizen as a form appreciation.

Lambe Turah Instagram account's owners have a good strategy to do social media. For example, they choose prime time hours to upload gossips, choose the hottest and up to date information that all of their posts are always expected and flooded with comments and like from its followers. With their tagline, gossip is a delayed fact, this account succeeded in swaying gossip maniacs between the netizen.

In a photo post, there's at least tens of thousands likes and hundreds to thousands comments. This of course shows that Lambe Turah's posts are always being expected by their followers. This achievement of course brings popularity and financial impact to the account's owners. Getting income from an Instagram account's ownership is surely not a shocking event. Instagram accounts owners with massive followers such as Lambe Turah will of course being scouted by online shop accounts or other parties to endorse their product. Here is Lambe Turah owners account on endorsement:

"Well we accept endorsement but we do not purely made this account for money. There was a time when we refuse endorsement, you know. But then our account got lost for three days, remember, three days. Now which to choose? Losing our account and do nothing for it or accept the money and keep the account? It's the later of course."

From the explanation above, the purpose of this account establishment is not only for financial benefit but then it contradicts the reality and the chaos happened in the past when the account was sold irrationally. According to the chronology of Lambe Turah and @ thenewbikingeregetan posts, this chaos 
started from the amount of money which was considered too small that it's considered only as 'salam tempel' which equals to angpao or pocket money. This what ignite the chaos that ended in the account's return to its previous owners, and the return of the money received by an agreed number.

Now, by the return of this account to its previous owners, advertisements are flourishing. And as a million follower account, this account has a very neat management. As can be seen on Lambe Turah account page that every promotion through Lambe Turah needs to contact Nanda Persanda as the business manager of Lambe Turah at the attached number.

According to the result of the interview, Lambe Turah account's owners are very selective in choosing ads. They separate it into two platforms. Advertisements that are not in line with Lambe Turah genre such as online shop, shop ads, skin care ads and others are put in their Insta-story which will be gone in 24 hour. It's of course much cheaper than the ads to upload on their page. There are at least ten ads per day on their Insta-story, while the ads put on their main page are around three to five ads per day such as a singer new song promotion, an off air event, movie launching, and the others which in line with Lambe Turah field in entertainment industry.

The price they ask for an Insta-story ad is Rp. 500.000 per ad but it goes up to millions rupiah for their account page ads. Those are fantastic price considering the number of ads they got per day. But the owners defended that they are considered pretty cheap compared to other accounts. They said, "Well we were the cheapest compared to others, we are far below the average."

In addition to the income form the ads, Lambe Turah also receives income from a television channel as informant or resource since 2017 in the morning entertainment talk show titled "Pagi Pagi Pasti Happy". With the amount of ads broadcasted in a television channel per day, we can imagine the income they receive everyday. Logically, the more sensational and updated an account, the more followers they got and the more followers they have, the more ads they receive and so the more income they receive from that advertisements.

With the success of Lambe Turah in gaining a lot of followers, the logic of that phenomenon above is that market will be available when there is demand. That Lambe Turah account exist, with many follower, and receives a lot of advertisements because there are already a lot of people following the account. Doesn't matter if the followers are haters or lovers, because truthfully a big number of follower is enough to prove an account's success.

Media credibility that has been built since a long time is beaten up by personal opinion of the netizen who are lazy to check and re-check the source of information, who'll always ignore fact as they see fact as unimportant factor. Fact becomes number two and viral is more important. The phenomena happened is often a story is told previously to the truth. Netizen like information closer to their life better, such as affairs, marriage, divorce, and other bombastic news.

That netizen trust strengthen a post truth era where objectivity and rationality let emotion and passion become biased to their trust even though fact show them otherwise.
This phenomena is the reason that Lambe Turah which always gives update on sensational and spectacular news is becoming a new idol for the netizen. Those sensational information later is called as worth news. It's undeniable that the wild flow of information is feeding up the hoaxes spread.

This is where Neo Liberalism Ideology rapidly grows, an individual or group freedom to make, spread and consume an information is unlimited. The market wants updated information, producer informs sources without any data verification been held. Old media is being left behind that they ask a gossip account of a social media as their resource.

The result of macro level analysis shows that neo liberalism ideology becomes a reference for gossip account Lambe Turah, and netizen enjoys information freedom as it happens now. Information freedom at the end of the day ends up in a post truth era where netizen are reluctant to verify sources and trust a source so much that they are unable to differentiate between fact and fiction.

\section{CONCLUSION}

The result of critical discourse analysis on micro level is that there is a social discourse which is a pretty hot topic on the community concerning pelakor or a man stealer that then being posted by Lambe Turah in their post about second madam or second wife that is considered disturbing a household harmony.

On the level of mezzo, a text production discourse can be seen from a biased attitude discourse of Lambe Turah account owners to the hurt first wife's and their captions explain that it's fitting that those men stealers being bashed. Disses that used by the account's owners use slank words and their authentic diction that's naughty and funny and full of metaphors. A biased attitude is shown by their encouragement to give a social punishment through cyber bullying by pelakor (men stealers) as they are considered as the parties that can destroy a household relationship. Meanwhile on the consumption side, bombastic reports like this receive a warm appreciation from the netizen proven from the number of likes and comments on those posts.

On the macro level, situational, institutional and social factors have big influences on the information that is posted by 2009 Lambe Turah account. The account takes advantage in the information freedom and account's owner's legitimation that is orientated on neo liberalism ideology. This strengthen the post truth era as netizen are now unable to differentiate between facts and fictions.

In other words, orientation of Lambe Turah account's owners is the market. The freedom of information is signed by the produces that inform sources without any process of data verification to the sources. The speed of information spread has become an important factor that beats up information validation. This made the old media being lefted that they ask gossip accounts in social media as they resources.

\section{REFERENCES}

[1] N. Fairclough, Critical Discourse Analysis. New York: Addison Wesley Longman, 1995. 
[2] V.P. Glaveanu, Psychology in the post-truth era. Australia: Europe' Journal Of Psychology, 2017.
[3] N. Fairclough, Language and Power. New York: Addison Wesley Longman, 1989. 